\title{
Editorial
}

\section{La gestión integral como una herramienta de la productividad}

Yuber Liliana Rodrígue*-Rojas, Ph. D.

Editora en jefe

Profesora de la Maestría en Calidad y Gestión Integral

Convenio Universidad Santo Tomás - Icontec

La gestión implica caminos lógicos en pro de la búsqueda de soluciones creativas ante los problemas de los procesos y la administración de la organización. Por lo cual, es indispensable contar con la participación de la alta dirección en la apropiación, por parte de la organización, de los sistemas de gestión basados en normas técnicas internacionales, entre ellos: calidad, ambiental, seguridad y salud en el trabajo como parte de la responsabilidad social empresarial. Aunado a ello, la investigación desarrollada por Ghodrati, Yiu y Wilkinson (2018) demuestra que la gestión laboral, la supervisión y el liderazgo y la planificación mejoran el nivel de rendimiento, de seguridad y salud en el trabajo.

De acuerdo con el estudio adelantado por HernándezVivanco, Bernardo y Cruz-Cázares (2018), el promover estos sistemas de gestión favorece el uso de tecnologías limpias en las organizaciones puesto que muestran una relación entre esta con los sistemas de gestión y con la innovación de productos sostenibles. Lo anterior conlleva a una mejora en la imagen y en el equilibrio entre los componentes social, económico y ambiental de las organizaciones. Este planteamiento es reforzado por el estudio de Lannelongue, González-Benito y Quiroz (2017), quienes indican que la gestión ambiental tiene un impacto positivo en la productividad laboral en organizaciones con baja intensidad de capital.

Además, Hernández-Vivanco, Cruz-Cázares y Bernardo (2018), en otra investigación, lograron demostrar que la integración total de los sistemas de gestión se relaciona positivamente con niveles más altos de eficiencia de innovación y esta a su vez tiene un efecto positivo en el rendimiento de las organizaciones. Por otra parte, según Shujahat et al. (2017), el conocimiento derivado de la productividad del trabajador media entre los procesos de gestión del conocimiento (creación y utilización del conocimiento) y la innovación. Este estudio apoya la necesidad de investigar en la relación conocimiento/trabajador/productividad, dado que el papel fundamental del conocimiento derivado del trabajador es el desafío más sorprendente para las ciencias de la gestión en el siglo XXI, y en palabras de Drucker, se hace necesario analizar al trabajador del conocimiento como un propulsor de la productividad de las organizaciones.

En este sentido y atendiendo a la amplia difusión que han tenido los sistemas de gestión en los ámbitos global, nacional y local, así como los beneficios e 
impactos de la implementación de normas técnicas en las organizaciones (Díaz y Rodríguez-Rojas, 2016), se requiere estudiar con mayor profundidad su relación con la productividad y la sostenibilidad organizacional, para así desarrollar nuevos métodos para la medición de la productividad, metodologías de optimización de la gestión e innovación en procesos y procedimientos.

La productividad, de acuerdo con Singh, Gupta y Juneja (2018), se entiende como el número de entradas que se convierten en salidas en un proceso productivo. De acuerdo con lo señalado por Morelos, Fontalvo y Vergara (2013), la productividad es uno de los elementos esenciales para conocer las capacidades de una organización, dado que contribuye en la determinación del resultado de la operación de un sistema de producción de bienes o servicios que incluye tanto la relación entre las salidas y las entradas del mismo como el valor agregado generado. Estos autores han logrado demostrar a través de su investigación que la implementación de un sistema de gestión de la calidad incide positivamente en los índices de productividad de las organizaciones estudiadas, aunado a ello, la aplicación de otros sistemas de gestión como el ambiental o el de seguridad y salud en el trabajo también contribuyen a la productividad.

Atendiendo a estas certezas, la revista SIGNOS Investigación en sistemas de gestión lanza un nuevo número en el que se describen los resultados de ocho investigaciones y un artículo de reflexión. Las investigaciones y la reflexión descritas muestran avances en diferentes temas relacionados, algunos de forma directa y otros de forma indirecta, con la gestión integral y sus contribuciones en la productividad de las organizaciones, a saber:

1. Planificación de un sistema de gestión integrado para una organización de investigación agropecuaria.
2. Medición del work engagement y su relación con la comunicación, liderazgo y TIC en una empresa editorial mexicana.

3. La gestión de la cadena de valor en un entorno competitivo y cambiante.

4. Lean manufacturing: 5 s y TPM, herramientas de mejora de la calidad. Caso empresa metalmecánica en Cartagena.

5. Guía "De regreso al trabajo", necesidad empresarial para la adecuada implementación de los procesos de rehabilitación, reincorporación y reubicación laboral dentro del sistema de gestión de seguridad y salud en el trabajo.

6. Diagnóstico de la situación actual de una empresa de servicios de alimentación con respecto al cumplimiento de los requisitos de la norma ISO 9001:2015 para un sistema de gestión de la calidad.

7. Propuesta para fortalecer el sistema de gestión de la calidad organizacional en una entidad financiera del sector público colombiano.

8. Estrategia de responsabilidad social empresarial de una terminal portuaria en Barranquilla, Colombia.

9. Auditoría interna como herramienta pedagógica para las organizaciones.

Los desarrollos investigativos antes mencionados y las contribuciones de las revisiones descritas producen un acercamiento desde elementos teórico-conceptuales y desde la práctica en el entendimiento de asuntos relacionados a la gestión y a la productividad en las organizaciones y espacios analizados. Por lo tanto, este número de la revista se convierte en un documento alusivo para profesionales especializados, consultores, 
auditores, formadores empresariales, investigadores y profesores universitarios interesados en conocer más sobre la gestión organizacional.

\section{REFERENCIAS}

Díaz, C., y Rodríguez-Rojas, Y. (2016). Beneficios e impactos de la implementación de normas técnicas en las organizaciones: una revisión sistemática. SIGNOS - Investigación en sistemas de gestión, 8(2), 133-167.

Ghodrati, N., Yiu, T. W., y Wilkinson, S. (2018). Unintended consequences of management strategies for improving labor productivity in construction industry. Journal of Safety Research, 67, 107-116.

Hernandez-Vivanco, A., Bernardo, M., y Cruz-Cázares, C. (2018). Sustainable innovation through management systems integration. Journal of Engineering and Technology Management, 49, 76-90.

Hernandez-Vivanco, A., Cruz-Cázares, C., y Bernardo, M. (2018). Openness and management systems integration: Pursuing innovation benefits. Journal of Cleaner Production, 196, 1176.

Lannelongue, G., González-Benito, J., y Quiroz, I. (2017). Environmental management and labour productivity: The moderating role of capital intensity. Journal of Environmental Management, 190, 158-169.

Morelos, J., Fontalvo, T., y Vergara, J. (2013). Incidencia de la certificación ISO 9001 en los indicadores de productividad y utilidad financiera de empresas de la zona industrial de Mamonal en Cartagena. Estudios Gerenciales, 29(126), 99-109.

Shujahat, M., Sousa, M. J., Hussain, S., Nawaz, F., Wang, M., y Umer, M. (2019). Translating the impact of knowledge management processes into knowledge-based innovation: The neglected and mediating role of knowledge-worker productivity. Journal of Business Research, 94, 442-450. Recuperado de https://doi.org/10.1016/j.jbusres.2017.11.001

Singh, G., Gupta, A., y Juneja, C. (2018). Productivity measurement of manufacturing system. Materials Today: Proceedings. 5(1, Part 1), 1483-1489. 



\section{Editorial}

\section{Integrated management as a productivity tool}

Yuber Liliana Rodrígue*-Rojas, Ph. D.

Editor-in-chief

Professor of the Master in Quality and Integrated Management

Santo Tomás - Icontec University Agreement

Management involves logical paths in search of creative solutions to the problems of the processes and the administration of the organization. Therefore, it is essential to have the participation of senior management in the embracement, by the organization, of management systems based on international technical standards, including: quality, environmental, occupational safety and health as part of corporate social responsibility. In addition to this, the research developed by Ghodrati, Yiu and Wilkinson (2018) shows that labor management, supervision and leadership and planning improve the level of performance, of occupational health and safety.

According to the study conducted by HernándezVivanco, Bernardo and Cruz-Cázares (2018), promoting these management systems favors the use of clean technologies in organizations since they show a relationship between the latter with management systems and with the innovation of sustainable products. This leads to an improvement in the image and in the balance between the social, economic and environmental components of the organizations. This approach is reinforced by the study by Lannelongue, González-Benito and Quiroz (2017), who indicate that environmental management has a positive impact on labor productivity in organizations with low capital intensity.

In addition, Hernández-Vivanco, Cruz-Cázares and Bernardo (2018), in another research, succeeded in demonstrating that the entire integration of management systems is positively related to higher levels of innovation efficiency and this in turn has a positive effect in the organizations' performance. On the other hand, according to Shujahat et al. (2017), the knowledge derived from the worker's productivity mediates between the processes of knowledge management (creation and use of knowledge) and innovation. This study supports the need to research in the relationship knowledge/worker/productivity, given that the pivotal role of knowledge derived from the worker is the most striking challenge for the management discipline in the 21st century, and in Drucker's words, it is necessary to analyze the knowledge worker as a promoter of the productivity of the organizations.

In this sense and taking into account the wide dissemination of management systems in the global, national and local circles, as well as the benefits and impacts 
of the implementation of technical standards in organizations (Díaz and Rodríguez-Rojas, 2016), it is necessary to study in greater depth its relationship with productivity and organizational sustainability, in order to develop new methods for measuring productivity, methodologies for optimizing management and innovation in processes and procedures.

Productivity, according to Singh, Gupta and Juneja (2018), is understood as the number of inputs that become outputs in a productive process. According to Morelos, Fontalvo and Vergara (2013), productivity is one of the essential elements to know the capabilities of an organization, given that it contributes in establishing the outcome of the operation of a goods or services production system that include both the relationship between the outputs and the inputs thereof and the added value generated. These authors have been able to demonstrate through their research that the implementation of a quality management system has a positive impact on the productivity ratio of the organizations studied, additionally, the application of other management systems such as environmental or occupational safety and health also contribute to productivity.

In response to these certainties, the journal SIGNOS Investigación en sistemas de gestión launches a new issue that describes the results of eight research and one reflection article. The research and reflection described show progress in different topics related, some directly and others indirectly, with the integral management and their contributions in the productivity of organizations, namely:

1. Planning of an integrated management system for an agricultural research organization.
2. Measurement of work engagement and its relationship with communication, leadership and ICT in a Mexican publishing company.

3. Value chain Management in a competitive and changing environment.

4. Lean manufacturing: $5 \mathrm{~S}$ and TPM, quality improvement tools. Case of metalworking company in Cartagena.

5. "Back to work" guide, business necessity for the proper implementation of the processes of labor rehabilitation, reincorporation and relocation within the occupational safety and health management system.

6. Diagnosis of the current situation of a food service company with respect to compliance with the ISO 9001:2015 standard requirements for a quality management system.

7. Proposal to strengthen the management system of organizational quality in a financial institution of the Colombian public sector.

8. Corporate social responsibility strategy of a port terminal in Barranquilla, Colombia.

9. Internal audit as a pedagogical tool for organizations.

The aforementioned research developments and the contributions of the reviews described produce an approach from theoretical-conceptual elements and from the practice in the understanding of matters related to management and productivity in the organizations and spaces analyzed. Therefore, this issue of the journal becomes an allusive document for specialized 
professionals, consultants, auditors, corporate trainers, researchers and university professors interested in learning more about organizational management.

\section{REFERENCES}

Díaz, C., y Rodríguez-Rojas, Y. (2016). Beneficios e impactos de la implementación de normas técnicas en las organizaciones: una revisión sistemática. SIGNOS - Investigación en sistemas de gestión, 8(2), 133-167.

Ghodrati, N., Yiu, T. W., and Wilkinson, S. (2018). Unintended consequences of management strategies for improving labor productivity in construction industry. Journal of Safety Research, 67, 107-116.

Hernandez-Vivanco, A., Bernardo, M., and Cruz-Cázares, C. (2018). Sustainable innovation through management systems integration. Journal of Engineering and Technology Management, 49, 76-90.

Hernandez-Vivanco, A., Cruz-Cázares, C., and Bernardo, M. (2018). Openness and management systems integration: Pursuing innovation benefits.

Journal of Cleaner Production, 196, 1176.

Lannelongue, G., González-Benito, J., and Quiroz, I. (2017). Environmental management and labour productivity: The moderating role of capital intensity. Journal of Environmental Management, 190, 158-169.

Morelos, J., Fontalvo, T., y Vergara, J. (2013). Incidencia de la certificación ISO 9001 en los indicadores de productividad y utilidad financiera de empresas de la zona industrial de Mamonal en Cartagena. Estudios Gerenciales, 29(126), 99-109.

Shujahat, M., Sousa, M. J., Hussain, S., Nawaz, F., Wang, M., and Umer, M. (2019). Translating the impact of knowledge management processes into knowledge-based innovation: The neglected and mediating role of knowledge-worker productivity. Journal of Business Research, 94, 442-450. Retrieved from https://doi.org/10.1016/j.jbusres.2017.11.001

Singh, G., Gupta, A., and Juneja, C. (2018). Productivity measurement of manufacturing system. $\mathrm{Ma}$ terials Today: Proceedings. 5(1, Part 1), 1483-1489. 



\section{Editorial}

\section{A gestão integral como uma ferramenta da produtividade}

Yuber Liliana Rodríguez-Rojas, Ph. D.

Editora chefe

Professora do Mestrado em Qualidade e Gestão Integral

Convênio Universidade Santo Tomás - Icontec

A gestão implica caminhos lógicos a favor da busca de soluções criativas perante os problemas dos processos e administração da organização. Pelo qual é indispensável contar com a participação da alta direção na apropriação, por parte da organização, dos sistemas de gestão baseados em normas técnicas internacionais, entre eles: qualidade, ambiental, segurança e saúde no trabalho como parte da responsabilidade social empresarial. Ligado a isso, a pesquisa desenvolvida por Ghodrati, Yiu e Wilkinson (2018) demonstra que a gestão laboral, a supervisão e a liderança e a planificação melhoram o nível de rendimento, de segurança e saúde no trabalho.

De acordo com o estudo realizado por HernándezVivanco, Bernardo e Cruz-Cázares (2018), promover estes sistemas de gestão favorece 0 uso de tecnologias limpas nas organizações devido a que mostram uma relação entre esta com os sistemas de gestão e com a inovação de produtos sustentáveis. $\mathrm{O}$ anterior acarreta uma melhora na imagem e no equilibrio entre os componentes sociais, econômicos e ambientais das organizações. Esta explicação é reforçada pelo estudo de Lannelongue, González-Benito e Quiroz (2017) que indicam que a gestão ambiental tem um impacto positivo na produtividade laboral nas organizações com baixa intensidade de capital.

Além, Hernández-Vivanco, Cruz-Cázares e Bernardo (2018) em outra pesquisa demonstraram que a integração total dos sistemas de gestão relaciona-se positivamente com níveis mais altos de eficiência de inovação e esta tem um efeito positivo no rendimento das organizações.

De outro lado, segundo Shujahat et al. (2017) o conhecimento derivado da produtividade do trabalhador media entre os processos de gestão do conhecimento (criação e utilização do conhecimento) e a inovação. Este estudo apoia a necessidade de pesquisar na relação conhecimento/trabalhador/produtividade, dado que o papel fundamental do conhecimento derivado do trabalhador é o desafio mais surpreendente para as ciências da gestão no século XXI, e em palavras de Drucker, se faz necessário analisar o trabalhador do conhecimento como um propulsor da produtividade das organizações.

Neste sentido e atendendo à ampla difusão que tem os sistemas de gestão nos ambitos globais, nacionais e 
locais, assim como os benefícios e impactos da implementação de normas técnicas nas organizações (Díaz e Rodríguez-Rojas, 2016), requer-se estudar com maior profundidade sua relação com a produtividade e a sustentabilidade organizacional, para assim desenvolver novos métodos para a medição da produtividade, metodologia de otimização da gestão e inovação em processos e procedimentos.

A produtividade, de acordo com Singh, Gupta e Juneja (2018), entende-se como o número de entradas que se convertem em saídas em um processo produtivo. De acordo com o assinalado por Morelos, Fontalvo e Vergara (2013) a produtividade é um dos elementos essenciais para conhecer as capacidades de uma organização, dado que contribui na determinação do resultado da operação de um sistema de produção de bens ou serviços que inclui tanto a relação entre as saídas e as entradas do mesmo como o valor agregado gerado. Estes autores têm demonstrado através da sua pesquisa que a implementação de um sistema de gestão da qualidade incide positivamente nos índices de produtividade das organizações estudadas, ligado a isso, a aplicação de outros sistemas de gestão como 0 ambiental ou de segurança e saúde no trabalho também contribuem na produtividade.

Atendendo a estas certezas, a revista SIGNOS Pesquisa em sistemas de gestão publica um novo número no qual se descrevem os resultados de oito pesquisas e um artigo de reflexão. As pesquisas e a reflexão descritas mostram avanços em diferentes temas relacionados, alguns de forma direta e outros de forma indireta, com a gestão integral e suas contribuições na produtividade das organizações, a saber:

1. Planificação de um sistema de gestão integrado para uma organização de pesquisa agropecuária.
2. Medição do work engagement e sua relação com a comunicação, liderança e TIC em uma empresa editorial mexicana.

3. A gestão da cadeia de valor em um entorno competitivo e cambiante

4. Lean manufacturing. 5 s e TPM, ferramentas para a melhora da qualidade. Caso da empresa metal mecânica em Cartagena

5. Guia "De volta ao trabalho", necessidade empresarial para a adequada implementação dos processos de reabilitação, reincorporarão e relocalização laboral dentro do sistema de gestão de segurança e saúde no trabalho.

6. Diagnóstico da situação atual de uma empresa de serviços de alimentação com respeito ao cumprimento dos requisitos da norma ISO 9001:2015 para um sistema de gestão da qualidade.

7. Proposta para fortalecer o sistema de gestão da qualidade organizacional em uma entidade financeira do sector público colombiano.

8. Estratégia de responsabilidade social empresarial de um terminal portuário em Barranquilla, Colômbia.

9. Auditoria interna como ferramenta pedagógica para as organizações.

Os desenvolvimentos de pesquisa antes mencionados e as contribuições das revisões descritas produzem uma aproximação desde elementos teórico-conceptuais e desde a prática no entendimento de assuntos relacionados com a gestão e produtividade nas organizações e espaços analisados. Por tanto, este número da revista se converte em um documento alusivo para 
profissionais especializados, consultores, auditores, formadores empresariais, pesquisadores e professores universitários interessados em conhecer mais sobre a gestão organizacional.

\section{REFERÊNCIAS}

Díaz, C., y Rodríguez-Rojas, Y. (2016). Beneficios e impactos de la implementación de normas técnicas en las organizaciones: una revisión sistemática. SIGNOS - Investigación en sistemas de gestión, 8(2), 133-167.

Ghodrati, N., Yiu, T. W., y Wilkinson, S. (2018). Unintended consequences of management strategies for improving labor productivity in construction industry. Journal of Safety Research, 67, 107-116.

Hernandez-Vivanco, A., Bernardo, M., y Cruz-Cázares, C. (2018). Sustainable innovation through management systems integration. Journal of Engineering and Technology Management, 49, 76-90.

Hernandez-Vivanco, A., Cruz-Cázares, C., y Bernardo, M. (2018). Openness and management systems integration: Pursuing innovation benefits. Journal of Cleaner Production, 196, 1176.

Lannelongue, G., González-Benito, J., y Quiroz, I. (2017). Environmental management and labour productivity: The moderating role of capital intensity. Journal of Environmental Management, 190, 158-169.

Morelos, J., Fontalvo, T., y Vergara, J. (2013). Incidencia de la certificación ISO 9001 en los indicadores de productividad y utilidad financiera de empresas de la zona industrial de Mamonal en Cartagena. Estudios Gerenciales, 29(126), 99-109.

Shujahat, M., Sousa, M. J., Hussain, S., Nawaz, F., Wang, M., y Umer, M. (2019). Translating the impact of knowledge management processes into knowledge-based innovation: The neglected and mediating role of knowledge-worker productivity. Journal of Business Research, 94, 442-450. Recuperado de https://doi.org/10.1016/j.jbusres.2017.11.001

Singh, G., Gupta, A., y Juneja, C. (2018). Productivity measurement of manufacturing system. Materials Today: Proceedings. 5(1, Part 1), 1483-1489. 